\title{
TRANSFORMASI KARAKTERISTIK KOMUNIKASI DI ERA KONVERGENSI MEDIA
}

\section{Transformation of Characteristics Communication Media in Convergence Era}

\author{
${ }^{1)}$ Gushevinalti, ${ }^{2)}$ Panji Suminar, ${ }^{3)}$ Heri Sunaryanto \\ 1) 2) 3)FISIP Universitas Bengkulu \\ 1) 2) 3)Jalan Raya Kandang Limun, Bengkulu
}

Diterima 27 Desember 2019/ Disetujui 06 Maret 2020

\begin{abstract}
The development of communication technology has caused a shift or change in the concept of communication in particular the characteristics of mass communication. This study aims to find changes about the characteristics of mass communication in the current era of media convergence. In addition, to describe new forms of media that can be categorized into mass communication. The research method uses a qualitative approach to data collection techniques through document studies and literature review and interviews in mass communication courses. The informants of this study were lecturers of mass communication courses at the Bachelor of Communication Studies and Journalism FISIP S1 University of Bengkulu, as well as two groups of students who explained the characteristics of mass communication. The results showed that the development of communication technology at this time had contributed thoughts in the discussion about the transformation of the characteristics of mass media communication from conventional to digital. New forms of media that can be categorized based on these characteristics are online media, such as print media that have been changed by online systems, digital television and radio streaming. The characteristics of the mass media in some literatures have changed in one direction or have been interactive.
\end{abstract}

Keywords; transformation, mass communication, convergence, new media, characteristics

\begin{abstract}
ABSTRAK
Perkembangan teknologi komunikasi telah menyebabkan pergeseran atau perubahan dalam konsep komunikasi khususnya karakteristik komunikasi massa. Penelitian ini bertujuan untuk menemukan perubahan tentang karakteristik komunikasi massa di era konvergensi media sekarang ini. Selain itu, untuk mendeskripsikan bentuk media baru yang dapat dikategori kedalam komunikasi massa. Metode penelitian menggunakan pendekatan kualitatif dengan teknik pengumpulan data melalui studi dokumen dan kajian literatur dan wawancara pada matakuliah komunikasi massa. Informan penelitian ini adalah dosen pengasuh matakuliah komunikasi massa di prodi S1 Ilmu Komunikasi dan S1 Jurnalistik FISIP Universitas Bengkulu, serta dua kelompok mahasiswa yang memaparkan tentang karakteristik komunikasi massa. Hasil penelitian menunjukkan bahwa perkembangan teknologi komunikasi saat ini telah memberikan kontribusi pemikiran pada pembahasan mengenai transformasi karakteristik komunikasi media massa dari yang konvensional menuju digital. Bentuk media baru yang dapat dikategorikan berdasarkan karakteristik tersebut yaitu media online, seperti media cetak yang dirubah dengan sistem online, televisi digital dan radio streaming. Karakteristik media massa dalam beberapa literature menjadi berubah kakteristiknya tidak satu arah lagi atau sudah interaktif.
\end{abstract}

Kata kunci; transformasi, komunikasi massa, konvergensi, media baru, karakteristik

\footnotetext{
*Korespondensi Penulis

Email : gushevinalti@yahoo.com, soeminar1962@yahoo.com,hsunaryanto55@gmail.com
} 


\section{PENDAHULUAN}

\section{Latar Belakang}

Saat ini indikasi terjadinya pergeseran atau transformasi perubahan karakteristik komunikasi semakin menguat. Pemanfaatan teknologi dalam media massa merupakan suatu keniscayaan yang tidak dapat dihindari. Internet menjadi pendorong utama tumbuhnya konvergensi media yang memungkinkan menyatunya berbagai ragam media konvensional yang kemudian dapat diakses melalui internet (Jenkins, 2004). Disisi lain perkembangan aneka perangkat memudahkan orang mengakses bermacam ragam konten, baik berita, hiburan maupun informasi lainnya.

Matakuliah Komunikasi Massa menjadi matakuliah wajib di jurusan Ilmu Komunikasi. Namun, referensi atau buku wajib yang ada digunakan oleh mahasiswa masih mengacu pada referensi pembahasan tentang komunikasi massa yang belum berbasis digital. Salah satunya adalah referensi Ardianto (2004) dalam bukunya Pengantar Komunikasi Massa, yang menjadi referensi matakuliah komunikasi massa di prodi ilmu komunikasi menyatakan beberapa karakteristik yang dimiliki oleh komunikasi massa antara lain adalah :

1. Komunikator Terlembagakan.

komunikasi massa itu melibatkan lembaga, dan komunikatornya bergerak dalam organisasi kompleks, maka proses pemberian pesan yang diberikan oleh komunikator harus bersifat sistematis dan terperinci.

2. Pesan Bersifat Umum.

Pesan dapat berupa fakta, peristiwa ataupun opini. Namun tidak semua fakta atau peristiwa yang terjadi di sekeliling kita dapat dimuat dalam media massa. Pesan komunikasi massa yang dikemas dalam bentuk apapun harus memenuhi kriteria pengting atau menarik.

3. Komunikan Anonim dan Heterogen.

Komunikan yang dimiliki komunikasi massa adalah anonim (tidak dikenal) dan heterogen ( terdiri dari berbagai unsur )

4. Media Massa Menimbulkan Keserempakan.

Keserempakan media massa itu adalah keserempakan kontak dengan sejumlah besar penduduk dalam jarak yang jauh dari komunikator, dan penduduk tersebut satu sama lainnya berada dalam keadaan terpisah.

5. Komunikasi Massa mengutamakan isi daripada hubungan

Dalam komunikasi massa, pesan harus disusun sedemikian rupa berdasarkan sistem tertentu dan disesuaikan karakteristik media massa yang digunakan. Di dalam komunikasi antarpersonal, yang menentukan efektivitas komunikasi bukanlah struktur, tetapi aspek hubungan manusia, bukan pada "apanya "tetapi " bagaimana". Sedangkan pada komunikasi massa menekankan pada "apanya "(Ardianto, 2004).

6. Komunikasi Massa bersifat satu arah Komunikator dan komunikan tidak dapat terlibat secara langsung, karena proses pada komunikasi massa yang menggunakan media massa.

7. Stimuli alat indra "Terbatas"

Stimulasi alat indra tergantung pada media massa. Pada surat kabar dan majalah, pembaca hanya melihat, pada media radio khalayak hanya mendengarkan, sedangkan pada media televisi dan film kita menggunakan indra pengelihatan dan pendengaran.

8. Umpan balik tertunda

Hal ini dikarenakan oleh jarak komunikator dengan komunikan yang berjauhan dan karakter komunikan yang anonim dan heterogen (Ardianto, 2004).

Seiring dengan perkembangan teknologi komunikasi seperti media massa dan dinamika sosial kemasyarakatan, tak dapat dipungkiri bahwa terjadi juga beberapa pergeseran atau perubahan dalam konsep komunikasi khususnya karakteristik komunikasi massa. Perubahan ini, gelagatnya, akan terus terjadi karena mengikuti perkembangan media dan teknologi informasi yang kian pesat.

Karakteristik komunikasi yang telah dipaparkan di atas menjadi penting untuk diperdebatkan karena bentuk media massa dan sifat yang melekat pada media tersebut bisa jadi berubah drastis karena perkembangan teknologi juga mengakibatkan perubahan karakteristik bentuk komunikasi khususnya komunikasi massa yang erat sekali dengan media massa. Salah satu karakteritik yang 
harus dikritisi adalah bahwa media saat ini tidak lagi satu arah, tetapi sebaliknya sudah berjalan dua arah. Untuk itulah penelitian ini menarik untuk dilakukan karena beberapa referensi tentang media massa belum memasukkan bentuk transformasi media massa.

Transformasi adalah sebuah proses perubahan secara berangsur-angsur sehingga sampai pada tahap ultimate, perubahan yang dilakukan dengan cara memberi respon terhadap pengaruh unsur eksternal dan internal yang akan mengarahkan perubahan dari bentuk yang sudah dikenal sebelumnya melalui proses menggandakan secara berulang-ulang atau melipatgandakan. Pada penelitian ini, konsep transformasi menunjukkan bahwa perubahan/pergeseran karakteristik terjadi pada komunikasi massa dan komunikasi antar pribadi sebagai akibat perkembangan teknologi komunikasi yang berbasis internet.

Istilah transformasi kini telah semakin popular pada media massa baik cetak dan elektronik, sehingga muncul bentuk baru yang dikenal dengan konvergensi, yang memungkinkan telah tergabungnya bentuk baru media dengan menggunakan teknologi baru.

Menelaah kategori sebuah media baru suatu media dikatakan baru ini dibagi menjadi tiga kemungkinan. Kemungkinan pertama, media dikatakan baru apabila terasa asing dan disajikan secara agresif, bahkan berulangulang. Kemungkinan kedua, penggunaan media baru sudah menjadi konsumsi kita sehari-hari, sehingga berdampak pada semakin berkurangnya rasa keingintahuan untuk menyelidiki lebih lanjut. Kemungkinan ketiga, perkiraan awal kebaruan dapat berubah
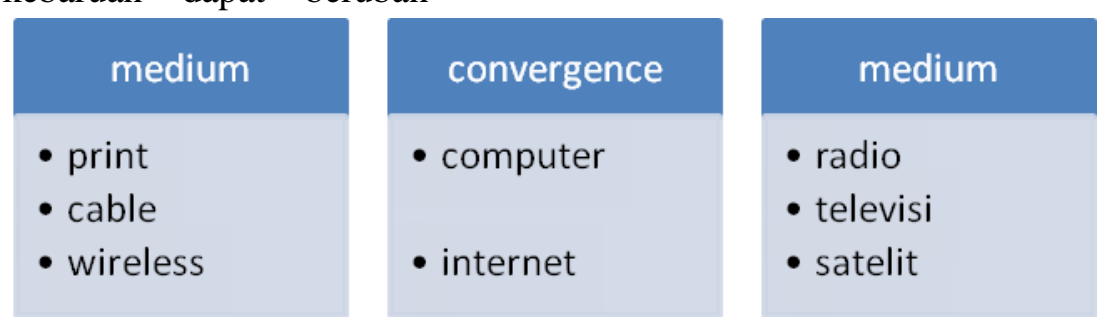

Gambar 1. Ilustrasi konvergensi media Sumber (Lawson-Borders, 2003) 
Teknologi tidak memiliki dampak langsung terhadap praktik budaya, karena efek yang timbul dimediasi melalui lembaga yang relevan. Dalam konteks ini lembaga tersebut adalah media massa (McQuail, 2012). Menurut McQuail (2012), munculnya media baru membuat beberapa perubahan, seperti digitalisasi dan konvergensi atas segala aspek media serta interaktivitas dan konnektivitas jaringan yang semakin meningkat. Berkembangnya teknologi juga memengaruhi perubahan produk jurnalistik dan pertumbuhan kamera digital atau video (R Diers, 2011).

Disamping perubahan atau pergeseran pada komunikasi massa, perkembangan teknologi juga mengubah paradigma terhadap komunikasi antar pribadi. Hampir semua referensi yang digunakan sebagai bahan pembelajaran oleh mahasiswa maupun dosen yang mengampu matakuliah komunikasi massa dan komunikasi antar pribadi belum memiliki kebaharuan dalam referensi yang menegaskan perubahan dalam beberapa karakteristik komunikasi tersebut, padahal matakuliah ini merupakan matakuliah wajib pada setiap program studi ilmu komunikasi. Walaupun sebenarnya dalam proses pembelajaran, pergeseran konsep telah menjadi diskusi yang hangat. Untuk itu penting dikaji ulang karakteristik komunikasi khususnya potensi mengenai bentuk-bentuk komunikasi, yakni kebaruan dalam konsep baru berbasis konvergensi media.

Dengan kata lain, perkembangan teknologi informasi dan komunikasi yang pesat tak hanya merubah peta dan platform industri media, namun juga mempengaruhi cara orang mengakses media sebagai sumber informasi. Ditambah lagi, teori komunikasi yang berkembang umumnya belum disesuaikan dengan konsep kekinian komunikasi. Sehingga penelitian ini menargetkan temuan karakteristik baru yang merekonseptual kembali komunikasi massa yang dinilai masih konvensional saat ini sehingga menuju pada sebuah engagement paradigm.

\section{Rumusan Masalah}

Berdasarkan latar belakang dan pertimbangan di atas maka rumusan masalah yang menarik untuk dikaji dalam penelitian ini adalah: Bagaimana transformasi karakteristik komunikasi massa yang terjadi pada era konvergensi media saat ini? Lalu, bagaimana bentuk media baru yang dikategori dalam komunikasi massa?

\section{Tujuan Penelitian}

Untuk mencapai target di atas, maka tujuan khusus penelitian ini adalah:

a. Menemukan perubahan tentang karakteristik komunikasi massa di era konvergensi media sekarang ini.

b. Mendeskripsikan bentuk media baru yang dapat dikategori kedalam komunikasi massa.

\section{Manfaat Penelitian}

Matakuliah komunikasi massa masih menggunakan referensi atau buku-buku acuan yang relatif lama (dibawah tahun 2000), sehingga acuan primer tersebut belum disesuaikan dengan perkembagan karakteristik kekinian. Dengan kata lain, belum ada kebaruan materi dari karakteristik yang lama menjadi karakteristik komunikasi yang baru. Hal ini disebabkan belum banyak penelitian yang merumuskan konsep baru berbasis konvergensi media.

\section{METODE PENELITIAN}

\section{Desain/Pendekatan Penellitian}

Tujuan khusus penelitian ini, yaitu menemukan perubahan karakteristik komunikasi massa di era konvergensi media sekarang ini. Kemudian meletakkan konsep baru (re-konseptualisasi) pada bentuk komunikasi massa sebagai teori baru menunjang materi perkuliahan di Prodi S1 Ilmu Komunikasi dan S1 Jurnalistik. Penelitian ini merupakan penelitian kualitatif dengan menggunakan metode deskriptif. Menurut Neuman (2014), penelitian deskriptif akan menghasilkan

gambaran dari detail spesifik dari sebuah situasi, keadaan sosial, atau hubungan.

Penelitian ini akan mengombinasikan beberapa jenis metode pengumpulan data, sesuai dengan tahapan data yang dibutuhkan guna menghasilkan output penelitian. Metodemetode tersebut adalah: a) Studi dokumen atau kajian literatur; b) $F G D c$ ) wawancara.

\section{Lokasi dan Subyek Penelitian}

Mengingat fokus penelitian ini adalah re-konseptualisasi karakteristik komunikasi, 
maka subyek penelitian ini Prodi Ilmu Komunikasi yang memiliki matakuliah komunikasi massa. Sehingga penentuan prodi ditentukan secara purposive.

Selanjutnya, yang menjadi subyek dalam penelitian ini adalah dosen yang mengajar komunikasi massa Jumlah informan tidak ditentukan namun akan menyesuaikan dengan kebutuhan informasi ketika dilakukan beberapa metode pengumpulan data. Selain dosen, mahasiswa yang sedang menempuh matakuliah ini juga menjadi subyek penelitian.

\section{Metode Pengumpulan Data}

Penelitian ini yang berupaya menghasilkan bahan ajar matakuliah komunikasi massa dan matakuliah komunikasi antar pribadi ini mengombinasikan beberapa jenis metode, sesuai dengan tahapan data yang dibutuhkan guna menghasilkan output penelitian. Metode-metode tersebut adalah:

a. Studi dokumen atau kajian literature

Penelitian ini menggunakan studi dokumen dalam tahapan inventarisasi data penelitian terkait dengan referensi atau bukubuku pengangan dalam matakuliah komunikasi massa dan komunikasi antar pribadi. Umumnya, referensi ini merupakanbuku-buku terbitan lama namun masih digunakan dalam perkuliahan.

Selain untuk keperluan analisis, studi dokumen berfungsi sebagai penunjang triangulasi, sehingga memperkuat validitas data penelitian. Sebagaimana diungkapkan oleh Daymon \& Holloway (2008), analisis dokumen memberi peneliti akses pada bukti dan pemikiran peneliti lain. Dokumen memudahkan peneliti menafsirkan lebih baik lagi kemungkinan rekonstruksi peristiwa yang dilaporkan partisipan penelitian. Selain itu, memungkinkan peneliti mengidentifikasi faktor-faktor yang selama ini diarahkan pada keputusan atau rangkaian tindakan tertentu.

\section{b. Wawancara}

Wawancara dilakukan kepada dosen pengasuh matakuliah komunikasi massa di Prodi Ilmu Komunikasi. Materi wawancara antara lain defenisi komunikasi massa, karakteristik komunikasi massa, bentuk-bentuk perubahan media massa, kontribusi era konvergensi media pada perubahan komunikasi massa. Selain itu wawancara juga serta diskusi kelompok dilakukan pada mahasiswa-mahasiswa yang mengambil matakuliah komunikasi massa tentang pengetahuan faktual karakteristik.

\section{Teknik Analisis Data}

Sebagai sebuah studi yang berpijak pada pendekatan kualitatif, maka hasil studi dokumen akan dianalisis dengan cara:

1. Reduksi data, yaitu memilah-milah data yang tidak beraturan menjadi potonganpotongan (chunks) yang lebih teratur. Prosesnya dengan mengoding, menyusunnya menjadi kategori (memoring), dan merangkumnya menjadi pola dan susunan yang sederhana.

2. Interpretasi, yaitu upaya mendapatkan makna dan pemahaman terhadap kata-kata dan tindakan para partisipan riset, dengan memunculkan konsep dan teori (atau teori berdasarkan generalisasi) yang menjelaskan temuan penelitian.

\section{Triagulasi penelitian}

Triangulasi adalah teknik pemeriksaan keabsahan data yang memanfaatkan sesuatu yang lain di luar data itu untuk keperluan pengecekan atau pembanding terhadap data itu (Moleong, 2009). Triangulasi yang digunakan dalam penelitian ini adalah triangulasi teori. Mengingat penelitian ini akan menghasilkan re-konseptualisasi mengenai karakteristik komunikasi massa dari referensi/buku yang lama yang masih dijadikan referensi mahasiswa.

\section{Peta Alur Penelitian}

Penelitian ini akan diawali dengan pemetaan karakteristik bentuk komunikasi massa secara konvensional melalui referensi yang digunakan oleh dosen dan mahasiswa dalam pembelajaran dikelas. Kemudian karakteristik ini disesuaikan dengan hadirnya teknologi komunikasi yang baru (New media) atau berbasis konvergensi/internet. Dengan demikian melahirkan bentuk baru (transformasi) karakteristik komunikasi massa. Luaran wajib penelitian ini adalah perbaharuan materi untuk matakuliah komunikasi massa. Luaran penelitian ini akan diterbitkan pada jurnal Bricolage, Jurnal komunikasi Universitas Bunda Mulia. Visualisasi peta alur penelitian terlihat pada bagan di bawah ini: 


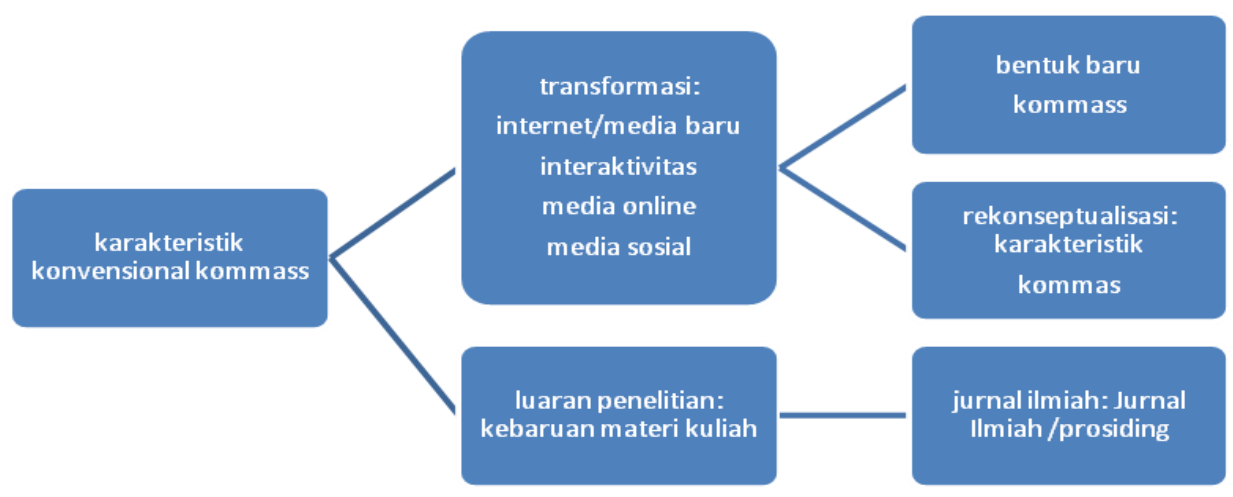

Gambar 2. Peta Alur Penelitian

(sumber: peneliti)

\section{HASIL DAN PEMBAHASAN}

\section{Hasil Penelitian}

Penelitian ini dilakukan pada kelas aktif matakuliah Komunikasi Massa. Matakuliah ini menjadi matkuliah wajib dan merupakan matakuliah dasar bagi sub bahasan matakuliah lanjutan seperti Manajemen Media Massa, Sosiologi Komunikasi Massa dan New Media. Pembahasan materi awal tentu saja sangat menentukan pemahaman mahasiswa mengenai media massa. Apalagi karakteristik media massa sangat jelas mengalami perubahan mendasar dalam bentuk, sifat dan karakteristiknya.

Proses presentasi yang dipaparkan oleh kelompok pada kelas yang berbeda adalah materi awal perkuliahan memberikan pandangan bahwa interaktivitas telah menjadi istilah untuk sejumlah pilihan media baru yang berkembang dari penyebaran cepat jalur akses internet, digitalisasi media, dan konvergensi media. Secara umum ditemukan konsep interaktifitas menggantikan komunikasi satu arah pada media massa konvensional dengan kemungkinan komunikasi dua arah dari web. Setiap individu dengan teknologi tepat guna sekarang dapat menghasilkan media onlinenya dan termasuk gambar, teks, dan yang lainnya.

Secara umum, pemahaman mahasiswa tentang karakteristik komunikasi massa masih berorientasi dengan karakteristik yang konvensional atau lama masih berdasarkan pengetahuan pada sumber bahan bacaan atau referensi Komunikasi Massa yang belum mengalami revisi. Padahal, mahasiswa sebagai digital natives sehari-hari kegiatannya sangat tergantung dengan internet. Dapat diasumsikan unsur lain dalam interaktivitas termasuk radio dan televisi, surat untuk editor, partisipasi pendengar dalam program tersebut, komputer dan program-program aplikasi teknologi sangat akrab dengan mahasiswa. Penelitian ini juga mengungkapkan bahwa mahasiswa menggunakan internet bukan sebagai sumber informasi untuk mendapatkan informasi yang mendukung akademiknya namun sebaliknya.

\section{Karakteristik Komunikasi Massa Konvensional}

Karakteristik yang dimiliki oleh komunikasi massa bentuk konvensional dengan betuk digital pada era ini ditemukan beberapa perubahan karakteristik. Triangulasi teori yang digunakan dalam penelitian ini memperoleh hasil kajian karakteriristik media massa di era konvengensi media sebagai berikut:

1. Komunikator Terlembagakan.

Pada era digital banyak sekali ditemukan media massa baru berbentuk online, namun dengan kemudahan untuk menyampaikan informasi, media baru tersebut mesti berbadan hukum karena sebagai dasar legalitas menjadi perusahaan pers. Media massa dalam berbagai bentuk cetak, 
elektronik dan online wajib menempuh verifikasi faktual dari dewan pers. Hal ini menunjukkan tanggungjawab sebagai perusahaan media pemberi informasi pada publik.

2. Pesan Bersifat Umum.

Pesan media massa tidak mengalami perubahanyang mendasar pada era ini, namun peran media menyampaikan fakta dan peristiwa mampu menangkal disinformasi. Sehingga pesan yang bersifat umum tentu saja menjadipenciri media digital.

3. Komunikannya yang Anonim dan Heterogen.

Pada kategori ini, terdapat kolaborasi yang erat antara bentuk media yang konvensional dengan digital. Komunikan pada media konvensional bisa jadi anonim tetapi pada media digital, komunikan selain anonim juga bisa saling mengenal. Karena, media digital membenuk jarigan komunikasi melalui instant messaging untuk penyebarluasan informasi. Biasanya antara khayalak media saling mengenal dalam instant messanging yang khusus dibuat untuk penyebaran informasi sebuah media massa online. Kategori heterogen memang menjadi karakteristik yang menetap antara bentuk digital dan konvensional. Derajat perbedaannya bisa secara demografis, geografis dan psikis.

4. Media Massa Menimbulkan Keserempakan.

Pada karakter ini tentu saja terdapat makna bahwa kecepatan informasi yang sampai pada khalayak tergantung dengan bentuk medianya. Jika pada media massa konvensioal, keserampakan terjadi tetapi legih lambat dibandingkan media online. Keserempakan media massa itu adalah keserempakan kontak dengan sejumlah besar penduduk dalam jarak yang jauh dari komunikator, dan penduduk tersebut satu sama lainnya berada dalam keadaan terpisah.

5. Komunikasi Massa mengutamakan isi daripada hubungan

Dalam komunikasi massa, pesan harus disusun sedemikian rupa berdasarkan sistem tertentu dan disesuaikan karakteristik media massa yang digunakan. Berbeda dengan komunikasi antarpersonal, yang menentukan efektivitas komunikasi bukanlah struktur, tetapi aspek hubungan manusia, bukan pada "apanya "tetapi " bagaimana". Sedangkan pada komunikasi massa menekankan pada "apanya ". Sehingga akurasi karya jurnalistik

6. Komunikasi Massa bersifat satu arah

Komunikator dan komunikan tidak dapat terlibat secara langsung, karena proses pada komunikasi massa yang menggunakan media massa. Karakteristik ini tidak berlaku dalam semua bentuk media pada era digital. Satu arah maksudnya adalah komunikan tidak bisa memberi feedback secara langsung pada media massa. Tetapi penelitian ini menyimpulkan bahwa era digital dengan beragam bentuk media yang memungkinkan khalayak dapat berinteraksi langsung dengan komunikator media.

7. Stimuli alat indra "Terbatas"

Semua bentuk media memiliki kelebihan dan kelemahan. Stimulasi alat indra tergantung pada media massa. Pada surat kabar dan majalah, pembaca hanya melihat, pada media radio khalayak hanya mendengarkan, sedangkan pada media televisi dan film kita menggunakan indra penglihatan dan pendengaran.

8. Umpan balik tertunda

Karakteristik ini sangat erat kaitannya dengan adanya media yang bersifat satu arah. Selain itu, dikarenakan oleh jarak komunikator dengan komunikan yang berjauhan dan karakter komunikan yang anonim dan heterogen. Pada era digital telah terjadi perubahan bahwa umpan balik dapat terjadi seketika informasi telah diakses oleh khalayak. Saluran penyampaian umpan balik bisa beragam, sehingga media massa juga harus siap dengan respon dari khalayak. Interaktivitas terjadi pada karakteristik ini.

Hasil penelitian melalui observasi menunjukkan bahwa karakteristik komunikasi massa yang selama ini digunakan dalam materi matakuliah komunikasi massa sudah tidak relevan mengingat hadirnya media baru yang berbasis internet serta membentuk kolaborasi baru. Misalnya menurut Makhrian bahwa saat ini banyak orang belum mampu memahami secara konsep telah terjadi perubahan dalam ciri khas komunikasi massa, dengan menyesuaikan karakteristik baru. Namun dari karakteristik yang baru, point komunikator 
yang terlembagakan tetap menjadi syarat utama. digitalisasi tetap menjadi kunci penentu pada semua kegiatan dan juga produk konvergensi media. Internet merupakan contoh yang paling mudah jika ingin melihat perubahan distribusi dan konvergensi media. Internet berbeda dengan media konvesional. Internet tidak hanya menyambungkan satu dengan point dengan satu point lain. Tapi juga dari satu point ke banyak point, menyambungkan individu dengan individu juga antara individu dengan orang banyak. Dan kita bisa melihat kontribusi yang ditawarkan dengan adanya konvergensi media ini.

Sementara itu, menurut Yudisiani karakteristik komunikasi massa yang konvensional sangat mudah untuk dibedakan dengan yang baru walaupun secara umum masih memiliki afisliasi yang sama antara media massa yang lama dan baru, artinya bisa saja perusahaannya satu korporasi namun bentuknya saja yang berubah digital. Jika dulu pers hanya digolongkan sebagai produk penerbitan yang melewati proses percetakan. Pers dalam arti luas adalah meliputi pelbagai kategori dan jenis media massa, baik suratkabar, radio, televisi, film, dan sebagainya.

Dengan demikian dapat disimpulkan bahwa "jurnalistik" adalah bentuk komunikasinya, bentuk kegiatan dan bentuk isinya, sedangkan "pers" adalah medium tempat jurnalistik dipublikasikan. Jika dilihat dari hasil akhirnya, "jurnalistik" adalah adalah hasil kegiatan pengolahan informasi yang akan disampaikan berupa berita, reportase, feature, dsb, maka "pers" adalah suratkabarnya, majalahnya, televisinya, atau internetnya. Singkat kata pers adalah medianya, sedangkan jurnalistik adalah isinya, hal ini juga sejalan dengan pendapat Muhtadi, 1999; Sumadiria, 2005; Kusumaningrat dan Kusumaningrat, 2005.

Media baru tersebut muncul dengan sifatnya yang semakin canggih. Karakteristik volume informasi dan pesan yang disampaikan semakin besar dan menjangkau seluruh dunia. Media baru yang dimaksudkan di sini tidak terbatas hanya pada media interaktif saja, tapi juga seluruh media konvensional yang ada.

Dengan jaringan internet sebagai saluran komunikasinya dan informasi interaktif yang menjangkau seluruh dunia, peranan media baru tersebut menjadi sangat dominan. Semua media lama akan menjadi tradisional jika tidak melibatkan diri dalam jaringan cyberspace. Semua itu merupakan prasyarat agar media mampu menjadi bagian dari sistem jaringan global.

Penelitian ini juga meminta pandangan dan peikiran dari salah satu dosen pengampu matakuliah dan pengamat jurnalisme di Bengkulu yaitu Andy Mahkrian. Menurutnya, transformasi teknologi menyebabkan industri media terpaksa berubah haluan untuk bisa bertahan dan menyesuaikan dengan selera pasar, namun tidak meninggalkan bentuk yang lama (konvensional). Selain itu menurutnya, media online terus berkembang dengan pemanfaatan teknologi, sehingga persaingan semakin ketat dan media dituntut memiliki kualitas informasi yang dapat dipertanggungjawabkan. Lebih lanjut dikatakan bahwa kajian dalam perkuliahan tentu saja mengikuti perkembangan media saat ini, tidak bisa bertahan pada pembahasan media konvensional semata.

Perubahan bentuk penyampaian pesan (dari print hingga siaran dan kini internet) berubah juga pada bentuk yang ada. Perubahan media komunikasi, maka struktur organisasi dan news room perlu menyesuaikan. Berubahnya media yang awalnya yang awalnya bersirkulasi harian, menit bahkan detik. Kemampuan yang dibutuhkan juga dengan adanya sifat mutimedia. Jadi masa depan media massa dapat dilihat pada dua hal yaitu perkembangan teknologi dan industri media massanya. Perkembangan teknologi menjadi penyokong perubahan perkembangan konvergensi media. Industri media massa menjadi dampak lain dari adanya era konvergensi media tersebut.

Salah satu penelitian yang menerangkan bentuk konvergensi pada media nasional dilakukan oleh (Diana, 2017) bahwa Pendefinisian kembali makna konvergensi menyimpulkan, Majalah Tempo, Koran Tempo, dan Tempo.co harus fokus mengembangkan platform digitalnya masingmasing dengan struktur yang terpisah. Namun, bukan berarti Tempo meninggalkan konvergensi media. Tempo memaknai bahwa pengembangan platform digital majalah dan koran sebagai bentuk baru konvergensi Tempo. Adapun Tempo kini menuju pada penerapan konvergensi 
multimedia yang tampak dari keinginan Tempo untuk mengembangkan Koran Tempo dan Majalah Tempo digital.

Kajian lainnya yang memperlihatkan tentang banyaknya transformasi dari konvensional menjadi digita yaitu sebuah platform baru Youtube menjadikan platform yang memungkinkan pengguna tidak hanya sebagai penonton audio visual saja namun juga dapat menjadi contentcreator yang hasilnya dapat dilihat banyak orang dari ragam latar belakang usia dan profesi. Kategori konten inilah yang secara sistem akan dikategorikan oleh sistem Youtube untuk memungkinkan dilakukannya sistem monetisasi yang berdampak pada adanya iklan. Bagi pengiklan hal ini menjadi peluang sebagai media promosi yang memudahkan untuk tercapainya jangkauan target pengguna produk/jasa dari merek tersebut (Christian, 2019).

Sementara itu, menurut Yudisiani salah satu pengampu matakuliah Komunikasi Massa di FISIP Universitas Bengkulu tentang konvergensi media menerangkan saat ini telah membawa gaya hidup baru pengguna menjadi lebih instan. Perubahan gaya hidup masyarakat yang menjadi kecanduan teknologi (cybermedia dan cybersociety). Adanya ketergantungan dimana segala sesuatu menjadi serba praktis dan otomatis. Menurutnya teknologi yang praktis memang bagus karena mempercepat dan memudahkan, namun hal ini juga bisa menjadi buruk jika kita tidak bijak Karena dengan adanya praktis kita cenderung menjadi orang yang "malas" dimana segala yang otomatis akan mempercepat hilangnya pekerjaan karena pekerjaan manusia sudah bisa digantikan dengan teknologi yang canggih".

Konvergensi media memungkinkan para profesional di bidang media massa untuk menyampaikan berita dan menghadirkan informasi dan hiburan, dengan menggunakan berbagai macam media. Komunikasi yang sudah dikonvergensikan menyediakan berbagai macam alat untuk penyampaian berita, dan memungkinkan konsumen untuk memilih tingkat interaktivitasnya, seraya mereka bisa mengarahkan sendiri penyampaian kontennya. Konvergensi media memungkinkan audiens (khalayak) media massa untuk berinteraksi dengan media massa dan bahkan mengisi konten media massa. Audiens sekarang dapat mengontrol kapan, di mana dan bagaimana mereka mengakses dan berhubungan dengan informasi, dalam berbagai jenisnya (García Avilés et al., 2009).

Media konvergensi didorong karena masuknya era media baru (new media) yang merupakan penggabungan antara data yang terdigitalisasi dan komputer yang terkoneksi dengan internet. McQuail (2010) menandai ciri new media:

a. Interaktivitas antara pengguna dengan sumber maupun sesama pengguna;

b. Social Presence (sosiabilititas), kehadiran pengguna secara karena kontak pribadi dengan orang lain sesama pengguna medium;

c. Media Richness, media dapat menjembatani perbedaan kerangka acuan, mengurangi ambiguitas, memberi isyarat yang lebih, melibatkan indera lebih banyak dan lebih pribadi.

d. Autonomy, pengguna dapat mengendalikan konten dan penggunaan dan telepas dari sumber;

e. Playfulness, berguna sebagai sarana hiburan dan kenikmatan;

f. Privacy, kebebasan penggunaan medium dan/atau konten;

g. Personalization, penggunaan medium bersifat personal dan unik.

Sehingga dapat dipahami, bahwa kehadiran media baru mengubah budaya termasuk didalamnya gaya hidup pengguna. Munculnya masyarakat digital/ masyarakat maya. Kemajuan teknologi konvergensi yang maju telah mempersempit jarak dan mempersingkat waktu. Jarak dan waktu sudah bukan masalah lagi, misalnya media lainnya tanpa perlu bertemu langsung. Hal ini menimbulkan masyarakat maya dimana komunikasi langsung secara face to face sudah tidak diminati lagi. Jika dikaitkan dengan karakteristik komunikasi massa maka dapat dikatakan bahwa pendekatan interaksi sosial membedakan media menurut seberapa dekat media dengan model interaksi tatap muka. Bentuk media penyiaran yang lebih lama dikatakan lebih menekankan pada penyebaran informasi yang mengurangi peluang adanya interaksi.

Media tersebut dianggap sebagai media informasional dan karenanya menjadi mediasi realitas bagi konsumen. Sebaliknya, media baru lebih interaktif dalam menciptakan pemahman baru tentang komunikasi tatap muka. Karakteristik komunikasi massa yang 
menyatakan bahwa komunikasi massa lebih mengutakan isi dari pada hubungan tentu saja dapat dibantah dengan temuan ini. Media baru bahkan memberikan sebuah variasi baru dalam berinteraksi yaitu dapat memberikan komentar langsung pada apa yang menjadi tema pemberitaan di media online.

\section{Bentuk Media Baru}

Dari hasil penelitian yang telah dilakukan melalui wawancara mendalam dengan informan dosen komunikasi massa dan hasil pengamatan sendiri oleh tim peneliti, maka dapat dipahami bahwa perkembangan teknologi media menyebabkan keniscayaan media konvensional berubah untuk mendapatkan keuntungan atau profit. Berikut ini akan dipaparkan karakteristik media baru yang telah berkontribusi dalam meubah bentuk media massa:

Pertama: Desentralisasi yaitu pengadaan dan pemilihan berita/informasi tidak lagi sepenuhnya berada di tangan pemasok komunikasi. Dalam hal ini, segi konten, konvergensi media mengacu pada kemampuan untuk menampilkan berbagai macam format konten media hanya melalui satu media saja. Contoh media konvergen yang berisi konten multimedia ini misalnya koran online Kompas.com. Melalui website, koran Kompas menjadi media konvergen yang dapat memuat berita dalam format teks, suara, dan video, bahkan dapat menyediakan wadah interaktif bagi komunitas pembacanya dalam format blog, bernama Kompasiana. Organisasi berita yang memanfaatkan website seperti Kompas ini, disebut juga convergent journalism. Dalam aspek jurnalisme, konten multimedia ini dapat pula menghasilkan konvergensi newsroom, di mana satu satu redaksi dapat menghasilkan berbagai output berita dengan konten multimedia. Dalam dimensi koordinasi, media-media yang berbeda kepemilikan bisa saja kerja sama seperti halnya media-media yang tergabung dalam satu kepemilikan. Konvergensi yang dilakukan dapat berupa sharing informasi, atau saling memanfaatkan fitur-fitur lain yang menguntungkan kedua belah pihak.
Kedua: berkemampuan tinggi: pengantaran melalui media kabel dan satelit mengatasi hambatan komunikasi yang disebabkan oleh pemancar siaran lainnya. Salah satu dimensi penting dari konvergensi ialah kolaborasi antar media. Kolaborasi ini sifatnya berbeda dengan konvergensi kepemilikan yang biasanya cenderung tergabung dalam tingkat newsroom. Dalam kolaborasi, konvergensi pun dapat dilakukan oleh media yang kepemilikannya berbeda ataupun jenis medianya yang berbeda. Konvergensi yang dilakukan biasanya berupa sharing content atau saling berbagai informasi di tingkat penyajian. Contoh kolaborasi ini misalnya kolaborasi antara headline berbagai koran nasional yang biasanya turut disiarkan sebagai salah satu berita di acara Apa Kabar Indonesia di TV One. Atau ketika berita ramalan cuaca di televisi turut dimuat di koran esok paginya (Hasil pembahasan kelompok 3 Ilmu komunikasi).

Ketiga: Bersifat interaktif: setiap pelaku komunikasi yang terlibat didalamnya dapat melakukan proses komunikasi timbal balik, dimana mereka dapat memilih, menjawab kembali, menukar informasi dan dihubungkan dengan yang lainnya secara langsung (hasil pembahasan kelompok Jurnalistik) .

Keempat: Fleksibel: fleksibel dalam hal ini meliputi bentuk, isi, dan penggunaannya. Dengan jaringan internet sebagai saluran komunikasinya dan informasi interaktif yang menjangkau seluruh dunia, peranan media baru tersebut menjadi sangat dominan. Semua media lama akan menjadi tradisional jika tidak melibatkan diri dalam jaringan cyberspace. Semua itu merupakan prasyarat agar media mampu menjadi bagian dari sistem jaringan global.

Media baru adalah istilah yang dimaksudkan untuk mencakup kemunculan digital, komputer, atau jaringan teknologi informasi dan komunikasi di akhir abad ke-20. Media massa baru memanfaatkan teknologi Interconnected Network (Internet), yang di definisikan sebagai medium yang terkoneksi sehingga pengguna terhubung dengan jaringan informasi 
Tabel 1. Perbedaan Media Lama dan Media Baru

\begin{tabular}{|c|c|}
\hline Karakteristik Media Massa Lama & Karakteristik Media Massa Baru \\
\hline $\begin{array}{l}\text { Meliputi televisi, radio, media cetak, informasi } \\
\text { dapat dipertanggungjawabkan dan bersifat formal }\end{array}$ & $\begin{array}{l}\text { Meliputi media online, seperti media cetak yang } \\
\text { diubah dalam bentuk digital, TV online, radio } \\
\text { streaming. }\end{array}$ \\
\hline $\begin{array}{l}\text { Harus menunggu informasipada jam yang } \\
\text { dijadwalkan }\end{array}$ & $\begin{array}{l}\text { Informasi pada situs tertentu tidak bersifat formal } \\
\text { sehingga kredibilas informasi tidak dapat } \\
\text { dipertanggungjawabkan }\end{array}$ \\
\hline $\begin{array}{l}\text { Khalayak tidak terhubung pada media dan } \\
\text { pengguna }\end{array}$ & an informasi \\
\hline $\begin{array}{l}\text { Komunikan anonim dan heterogen } \\
\text { Mengutamakan isi daripada hubungan pada } \\
\text { kondisi tertentu }\end{array}$ & $\begin{array}{l}\text { Pengguna dapat terhubung secara langsung } \\
\text { tidak memungkinkan bersinggungan dengan } \\
\text { ruang pribadi }\end{array}$ \\
\hline $\mathrm{k}$ bersifat tertunda dan tidak langsung & $\begin{array}{l}\text { Umpan balik dapat disampaikan langsung seperti } \\
\text { memberi komentar setelah membaca berita }\end{array}$ \\
\hline \multirow[t]{2}{*}{$\begin{array}{l}\text { Khalayak tidak memiliki keleluasaan mencari } \\
\text { informasi diluar jadwal yang telah ditentukan }\end{array}$} & $\begin{array}{l}\text { Komunikan dapat diketahui pada registerasi awal } \\
\text { ketika ingin mengakses media online seperti } \\
\text { kompas.com }\end{array}$ \\
\hline & $\begin{array}{l}\text { Khalayak memiliki keleluasan menentukan } \\
\text { informasi apa yang diinginkannya }\end{array}$ \\
\hline $\begin{array}{c}\text { Tidak memungkinkan bersinggunan di ruang } \\
\text { pribadi }\end{array}$ & $\begin{array}{l}\text { Memungkinkan bersinggungan diruang pribadi } \\
\text { seperti menggunakan ponsel }\end{array}$ \\
\hline
\end{tabular}

(wawancara penelitian dan studi dokumen, tahun 2018)

\section{Pembahasan}

Media massa baru telah mengalami perubahan/transformasi bentuk yang ditandai dengan digunakannya internet sebagai basis sentralnya, yang sangat berbeda dengan media konvensional. Dibawah ini yang merupakan bentuk dari media massa baru dapat dikategorikan berikut ini:

a. Jurnalisme Online

Jurnalisme online telah memicu tren alternatif, mengklaim bahwa jurnalisme online telah mengubah segala aktivitas jurnalistik dan kegiatan lama profesi jurnalisme.

$$
\text { J.Pavlik (2001) menyebut }
$$

jurnalisme online sebagai "contextualized journalism" yang mengintegrasikan tiga model komunikasi, yaitu kemampuan multimedia berdasarkan platform digital, kualitas-kualitas interaktif komunikasi online, dan fitur-fitur yang dapat ditata dengan berbagai variasi (costomizable features). Perbedaan utama yang ada di antara jurnalisme online dan media massa tradisional:

1. Kapasitas luas -halaman web bisa menampung naskah sangat panjang Informasi yang termuat bisa dikatakan tanpa batas karena didukung media penyimpanan data yang ada di server komputer dan sistem global. Informasi yang pernah disediakan akan tetap tersimpan, dan dapat ditambah kapan saja, dan pembaca dapat mencarinya dengan mesin pencari (search engine). 
2. Pemuatan dan editing naskah bisa kapan saja dan di mana saja.

3. Jadwal terbit bisa kapan saja bisa, setiap saat.

4. Cepat, begitu di-upload langsung bisa diakses semua orang.

Kejadian atau peristiwa yang terjadi di lapangan dapat langsung di upload ke dalam situs web media online ini, tanpa harus menunggu hitungan menit, jam atau hari, seperti yang terjadi pada media elektronik atau media cetak. Dengan demikian mempercepat distribusi informasi ke pasar (pengakses), dengan jangkauan global lewat jaringan internet, dan dalam waktu bersamaan .dan umumnya informasi yang ada tertuang dalam bentuk data dan fakta bukan cerita.

5. Menjangkau seluruh dunia yang memiliki akses internet.

6. Aktual, berisi info aktual karena kemudahan dan kecepatan penyajian.

7. Update, pembaruan informasi terus dan dapat dilakukan kapan saja.

8. Interaktif, dua arah, dan "egaliter" dengan adanya fasilitas kolom komentar, chat room, polling, dsb.

Salah satu keunggulan media online ini yang paling membedakan dirinya dengan media lain adalah fungsi interaktif. Model komunikasi yang digunakan media konvensional biasanya bersifat searah (linear) dan bertolak dari kecenderungan sepihak dari atas (top-down).

9. Terdokumentasi, informasi tersimpan di "bank data" (arsip) dan dapat ditemukan melalui "link", "artikel terkait", dan fasilitas "cari" ( search).

10. Terhubung dengan sumber lain (hyperlink)yang berkaitan dengan informasi tersaji.

Setiap data dan informasi yang disajikan dapat dihubungkan dengan sumber lain yang juga berkaitan dengan informasi tersebut, atau disambungkan ke bank data yang dimiliki media tersebut atau dari sumber-sumber luar. Karakter hyperlink ini juga membuat para pengakses bisa berhubungan dengan pengakses lainnya ketika masuk ke sebuah situs media online dan menggunakan fasilitas yang sama dalam media tersebut, misalnya dalamchatroom, lewat email atau games. Sejumlah karakteristik media baru yang muncul pada periode tahun 1980-an tersebut antara lain berkaitan dengan digital, virtual, hypertextual dan berjejaring. Beberapa karakteristik tersebut dapat dikatakan sebuah 'kualitas' yang dimiliki sebuah medium atau teknologi yang dimaksud.

Dengan berbagai ciri yang melekat pada jurnalisme online di atas, maka dapat dikatakan bahwa secara nyata terdapat perbedaan yang cukup mencolok pada jurnalisme online dibanding media konvensional. Dengan demikian. kelebihan dari internet sebagai media komunikasi adalah kemampuannya dalam mengubah alur komunikasi yang searah (dari komunikator ke komunikan) menjadi dua arah (dari komunikan ke komunikator). Sifat interaktif inilah yang menyebabkan internet mejadi media yang memperlebar ruang-ruang demokrasi, sebab masyarakat tak lagi sekedar objek pemberitaan tetapi juga bisa jadi subjek. Jurnalisme online ini dapat berupa media online, radio streaming, dan televisi digital.

\section{b. Televisi digital}

Digital adalah perubahan dari data input menjadi angka. Media digital mengambil bentuk data seperti cahaya dan suara yang ada dalam teks tertulis, foto, hingga rekaman gambar yang bergerak, kemudian diubah menjadi angka dalam bentuk disk drive, drive memory hingga sumber-sumber online.

Hal ini tentu berbeda dengan media analog yang mengubah data input, misalkan suara nyanyin seseorang, menjadi obyek lain seperti alur pada piringan hitam atau partikel magnetik pada pita. Digital dalam hal ini bisa dikatakan sebagai sebuah karakteristik yang dapat diarahkan untuk sebuah tujuan, seperti dimanfaatkan untuk berbagai macam kebutuhan atau mungkin justru dapat dieksploitasi.

Televisi digital atau DTV adalah jenis televisi yang menggunakan modulasidigital dan sistem kompresi untuk menyiarkan sinyal gambar, suara, dan data ke pesawat televisi. Televisi digital merupakan alat yang digunakan untuk menangkap siaran TV digital, 
perkembangan dari sistem siaran analog ke digital yang mengubah informasi menjadi sinyal digital berbentuk bit data seperti komputer.

Karakteristik Televisi Digital yaitu televisi digital menggunakan modulasi digital dan sistem kompresi dalam menyiarkan sinyal gambar, suara dan data ke televisi. Televisi digital menggunakan bit (data) komputer. Sarana televisi digital menggunakan media internet (Oliver, 2013).

Proses transformasi seperti yang ditemukan pada televisi digital disebut dengan dari analog menuju digital. Inovasi utama dalam bidang teknologi ialah kemampuan media untuk bertransisi secara virtual dari teknologi analog ke digital. 'Dunia Analog' ialah dunia yang selalu terwujud secara fisik, karena setiap impuls pesan, yang berupa suara, teks, gambar, atau bunyi, memiliki jalur penerimaannya masing-masing. Contohnya ialah radio, televisi, atau mikrofon. Perkembangan teknologi menjadi digital memungkinkan sebuah media untuk menghantarkan segala jenis gelombang dalam satu jalur frekuensi saja. Gambar, suara, teks, video, dan segala jenis pesan lainnya digabung dan dimanipulasi dalam satu format yang sama, menjadi sebuah instruksi yang terdiri dari rangkaian kode biner (angka 0 dan 1). Menurut Mirabito dan Morgenstern (2004: 21), keuntungan yang dapat diperoleh dari penggunaan sistem digital antara lain, computer compatibility dan integrity of the data when transmitted yang berarti kemampuan perangkat digital untuk terhubung dan transfer data ke perangkat digital lain. Contohnya, kamera digital, handphone, iPod, dapat tersambung ke sebuah computer. Sistem multiplexing memungkinkan banyak sinyal dapat ditumpangkan pada satu pemancar sehingga lebih efektif. Sistem encoding digital juga lebih flexible sehingga data-data yang tersimpan dapat disimpan, dimodifikasi, ditransfer, dan dimanipulasi untuk berbagai kepentingan. Contohnya ialah gambar dari kamera digital dapat ditransfer ke komputer secara mudah, diedit melalui Photoshop, dan dikonversi menjadi berbagai format, mulai dari JPG, PNG, GIF, atau bahkan dirangkai menjadi video slideshow.

Inovasi teknologi kedua yang menjadi titik penting konvergensi ialah persebaran internet yang dapat menghubungkan computer dalam suatu jaringan. Dengan terhubung melalui internet, hampir seluruh konten informasi dari media apapun, tersedia kapanpun dan dimanapun, tanpa terbatas ruang dan waktu seperti jika kita menggunakan media tradisional. Kini bisa saja koran dibaca dalam genggaman telapak tangan, sambil mendengarkan musik, diselingi chatting di messenger, atau sesekali mengupdate status via Twitter. Pagi, ataupun sore, sambil duduk bersantai di rumah, atau ketika terjebak macet dalam mobil. Semua itu mungkin dilakukan melalui smartphone.

Dengan dua fitur terpenting teknologi di atas, maka jelaslah bahwa dimensi teknologi dalam konvergensi merujuk pada kemampuan teknologi digital untuk menyimpan, memanipulasi, dan memodifikasi segalam jenis informasi di dalam komputer. Dan melalui internet, segala macam perangkat berbasis komputer dapat saling terhubung untuk saling berbagi segala jenis konten informasi tersebut.

Karakteristik yang baru komunikasi massa adalah komunikator melembaga, Meliputi media online, seperti media cetak yang diubah dalam bentuk digital, TV online, radio streaming, Informasi pada situs tertentu tidak bersifat formal sehingga kredibilas informasi tidak dapat dipertanggungjawabkan, mudah dalam pencarian informasi, pengguna dapat terhubung secara langsung, tidak memungkinkan bersinggungan dengan ruang pribadi, umpan balik dapat disampaikan langsung seperti memberi komentar setelah membaca berita, komunikan dapat diketahui pada registrasi awal ketika ingin mengakses media online seperti kompas.com, khalayak memiliki keleluasan menentukan informasi apa yang diinginkannya, dan memungkinkan persinggungan diruang pribadi seperti menggunakan ponsel.

Siaran menggunakan sistem digital memiliki ketahanan terhadap gangguan dan mudah untuk diperbaiki kode digitalnya melalui kode koreksi error. Akibatnya adalah kualitas gambar dan suara yang jauh lebih akurat dan beresolusi tinggi dibandingkan siaran televisi analog. Selain itu siaran televisi digital dapat menggunakan daya yang rendah.

Siaran televisi digital terestrial dapat diterima oleh sistem penerimaan televisi analog dan sistem penerimaan televisi bergerak. TV Digital memiliki fungsi interaktif 
dimana pengguna dapat menggunakannya seperti internet. Dengan demikian, karateristik televisi digital berbeda dengan televisi analog yangbersifat satu arah.

TV internet jika situs (baik itu situs, blog, atau akun di layanan simpan video) memiliki tayangan video yang terkonsep, terupdate, kontinu, dan bisa diakses oleh publik secara bebas, apa pun bentuk pendistribusiannya.(Kusuma, $10: 2009$ )

\section{c. Radio Streaming}

Pendengar radio saat ini dapat mengakses siaran radio di mana saja dan kapan saja melalui semua saluran media komunikasi yang dapat mendukungnya. Contohnya, melalui streaming atau internet, bisa dirasakan bahwa siaran radio akan lebih mudah diakses dan lebih berkualitas dalam suara. Bukan hanya untuk didengar, dengan perkembangan teknologi, konten siaran dapat juga disimpan. Podcast adalah pesan yang direkam atau program audio yang didistribusikan melalui proses mengunduh ke komputer atau media player portable lainnya (Straubhaar, 2011). Penyajian siaran radio dalam teknologi internet juga menampilkan informasi lain di dalam website. Tampilan website yang dibuat sedemikian rupa beserta konten yang di dalamnya memberikan nilai tambahan bagi selain akses ke siaran itu sendiri.

Efek terbesar dalam konvergensi media dalam konteks ini terjadi persaingan ekonomi, dimana media membutuhkan keuntungan yang banyak dari ongkos produksi dan operasional yang juga tak sedikit. Akibatnya suatu media tidak mudah bertahan di tengah persaingan pasar media yang begitu ketat. Media butuh kerja keras untuk merebut posisi sebagai pemimpin pasar, menjual semua program pada pengiklan dan mencapai oplah sebanyak-banyaknya dari media lain. Dalam persaingan media di Indonesia, persaingan sangat dirasa ketat, bahkan sudah ada beberapa perusahaan media yang mengalami kebangkrutan.

Salah satu media yang mengalami kepahitan di Indonesia yang ikut terkena dampak adalah Harian Kompas. Koran yang terbit sejak 28 Juni 1965 tersebut pun menjadi bagian dari pahitnya kenyataan turunnya tren media cetak. Koran nasional terbesar ini pun turut mengalami penurunan oplah, terutama sejak berkembangnya media berbasis elektronik.

Meski begitu, Kompas tetap melakukan usaha untuk mengikuti perkembangan zaman. Pada 2009, mereka meluncurkan sistem baru mengakses berita utama, yakni melalui augmented reality. Hal tersebut membangun hubungan antara berita utama di media cetak dan database digital. Pembaca bisa memperluas informasi yang didapatnya dari koran biasa, dengan cara melakukan pemindaian kode tertentu lewat kamera di gawainya, yang akan membuka tautan di laman internet yang berisi informasi tambahan. (Habibi, 2010 dalam Leksono, 2017). Lalu Kompas.id memang hadir di tengah turunnya tren media cetak yang semakin marak terjadi, terutama setelah internet hadir dan memunculkan bentukbentuk media baru.

Turunnya tren media cetak tidak terjadi karena jurnalismenya yang 'ketinggalan'. Selama ini banyak orang yang merasa kesulitan untuk berlangganan Harian Kompas, karena harus mencari agen terlebih dulu, meskipun untuk eceran banyak bisa didapatkan di toko-toko tertentu. Melalui Kompas.id, orang bisa memilih untuk berlangganan Harian Kompas, baik dalam bentuk cetak maupun digital (Leksono et al., 2017)

Sebagai sebuah bentuk baru, konvergensi media merupakan proses penggabungan antara media, industri telekomunikasi dan komputasi, dan penyatuan segala bentuk komunikasi termediasi dalam bentuk digital (Sediyaningsih, 2018). Inilah yang menjadi konsep yang menggeserkan bentuk karakteristik komunikasi massa di era ini. Fenomena perkembangan industri media ini, lama-kelamaan menimbulkan persaingan yang ketat di antara media tersebut, mulai dari belanja iklan, produksi dan reproduksi program, penguasaan pasar

dan perebutan konsumen, sampai pada persaingan teknologi media yangtak terhindarkan.

Karenanya, konvergensi media memberikan jalan terjadinya penurunan (divergence) atau pemisahan diri (de-merger). De-convergence secara cepat menggantikan model konvergensi media di tengah gagalnya konsep penggabungan dan akuisisi (merger and acquisitions atau M\&As) lebih dari satu 
media dalam satu perusahaan di abad ke-21 ini (Jin, 2012).

Industri media massa mengalami perkembangan yang pesat, indutri media massa telah berubah bukan semata-mata sebagai industri yang mementingkan aspek idealis saja seperti halnya alat sosial politik dan budaya tetapi telah mengubah dirinya menjadi institusi yang juga mengejar keuntungan finansial juga. Temuan ini sejalan dengan konsep konvergensi yang menerapkan Engagement Pyramid (Piramida Keterlibatan) adalah konsep yang pertama kali dicetuskan oleh Charlene $\mathrm{Li}$ dalam bukunya Open Leadership (Baughan,

2019:61). Engagement pyramid menggambarkan bagaimana individu sebagai konsumen terlibat dalam proses penciptaan sebuah produk, image atau brand di era digital (Marta, Pricillia, Kasasih, \& Iskandar, 2015:24). Piramida ini tersusun dari lima tahapan keterlibatan, yaitu:

1. Melihat (watching), pada tahap ini keterlibatan individu masih rendah, bersifat pasif, misalnya hanya membaca, atau mengklik sebuah situs, menonton video.

2. Berbagi (sharing), pada tahap ini, keterlibatan individu mulai ada, namun belum sepenuhnya melibatkan diri. Misalnya dengan melakukan retweet, repost, regram.

3. Berkomentar (commenting), pada tahap ini individu meningkat keterlibatannya dengan berinteraksi secara aktif, misalnya dengan menelepon, mengomentari pada kolom reply di media sosial.

4. Memproduksi (producing), pada tahap ini individu sebagai konsumen secara sengaja dilibatkan oleh produsen dalam proses produksi. Misalnya, menjadi narasumber, dikutip pendapatnya.

5. Mengkurasi (currating), pada tahap ini individu sebagai konsumen memiliki kedudukan yang sama dengan produsen, turut menyeleksi dan mempertimbangkan apakah suatu produk layak, perlu atau sangat penting bagi publik (Agung et al., 2019).

Hasil penelitian menujukkan bahwa mahasiswa mampu mereflesikan bagaimana karakteristik komunikasi yang telah mengalami pergeseran konsep. Sebut saja bahwa dalam sebuah buku komunikasi massa terdapat karakeristik komunikasi massa bersifat satu arah. Pada penelitian ini diperdebatkan bahwa konsep satu arah tentu saja tidak bisa diberlakukan dalam semua bentuk media baik audio, visual dan audiovisual. Apalagi di era digital, seperti konsep mengenai Engagement pyramid diatas sangat memungkinkan khalayak memberikan respon dengan sangat cepat dan interaktif. Apalagi jenis media massa yang elektronik. Karakteristik yang bersifat satu arah dimungkinkan pada bentuk media cetak. Sehingga butuh waktu yang tidak serta merta bagi audience memberi feedback padakomunikatir/medianya.

Digitalisasi telah menjadi salah satu pendorong utama perubahan sifat dan karakteristik jurnalisme, karena digitalisasi memengaruhi nilai berita, etika profesional, arus kerja, kondisi kerja, dan manajemen ruang redaksi. Namun terdapat juga sisi positifnya, digitalisasi meningkatkan akses warga terhadap informasi dan saluran diseminasi, tetapi pada saat yang sama juga berpotensi memunculkan sejumlah praktik non-etis, yang paling umum sekaligus mengkhawatirkan adalah plagiarisme, duplikasi dan kurangnya verifikasi. Akibatnya, peluang terjadi disinformasi dan

bahkan penyebaran hoax semakin besar.

\section{KESIMPULAN DAN SARAN}

\section{Kesimpulan}

Berdasarkan hasil penelitian dan pembahasan dapat ditarik kesimpulan secara umum bahwa transformasi ini berartiadanya perpindahan dari zaman transmisi satu arah ke zaman baru perbincangan dua arah dan mengubah sifat serta tujuan komunikasi itu sendiri. Konvergensi media merupakan bukti kedinamisan dunia yang selalu mengalami perubahan. Bentuk baru dari media massa adalah jurnalisme online, radio streaming, televisi digital yang telah menerapkan karakteristik tersebut.

Secara umum, media massa baru saat ini memberi kemudahan masyarakat bisa langsung memberikan umpan balik terhadap informasi-informasi yang disampaikan. Media konvergen memunculkan karakter baru yang makin interaktif, dimana penggunanya mampu berkomunikasi secara langsung dan memperoleh teknologi manusia dan masyarakat mendapatkan informasi lebih cepat. Disisi lain, kemudahan media 
massajuga menuai bahaya yaitu akurasi pemberitaan jauh dari aktualitas karena harus disajikan secara cepat tanpa gatekeeper profesional. Disinilah letak re- konseptualisasi tentang komunikasi massa, bahwa khalayak dapat melakukan interaksi dengan media (tidak satu arah) tanpa harus menunggu waktu yang lain seperti yang terjadi pada era sebelum digital.

\section{Saran}

Saran dalam penelitian ini adalah:

1. Sebagai matakuliah wajib pada prodi Ilmu Komunikasi, materi matakuliah komunikasi massa dapat menyesuaikan karakteristik yang bersifat digital.

2. Terbatasnya referensi yang baru tentang karakteristik komunikasi massa diharapkan hasil penelitian ini menjadi salah satu acuan pada materi Komunikasi Massa.

\section{DAFTAR PUSTAKA}

Agung, A., Prihandari, I., \& Danadharta, I. (2019). Keberlanjutan Jurnalistik Sehat Di Era Konvergensi Daring Suarasurabaya.Net Dengan Pendekatan Engagement Pyramid. Bricolage: Jurnal Magister Ilmu Komunikasi, 5(2), 177194.

https://journal.ubm.ac.id/index.php/bricol age/article/view/1855/1556

Christian, M. (2019). Telaah Keniscayaan Iklan Di Kanal Youtube Sebagai Perilaku Khalayak Di Kalangan Milenial. Jurnal Magister Ilmu Komunikasi Universitas Bunda Mulia, 5(2), 141-158.

Diana, L. (2017). De-convergence Newsroom Media di Indonesia Studi Kasus terhadap Tempo Inti Media. Jurnal Ilmu Komunikasi ULTIMACOMM UMN, 9(2), $15-45$.

http://ejournals.umn.ac.id/index.php/FIK OM

García Avilés, J. A., Meier, K., Kaltenbrunner, A., Carvajal, M., \& Kraus, D. (2009). Newsroom integration in Austria, Spain and Germany: Models of media convergence. Journalism Practice, 3(3), 285-303.

https://doi.org/10.1080/17512780902798
638

Jenkins, H. (2004). The Cultural Logic of Media Convergence. International Journal of Cultural Studies, 7(1), 33-43. https://doi.org/10.1177/13678779040406 03

Jin, D. Y. (2012). The new wave of deconvergence: A new business model of the communication industry in the 21st century. Media, Culture and Society, 34(6), 761-772. https://doi.org/10.1177/01634437124489 52

Kusumah, Yuliandi (2009) Beken Dengan, TV On Line, Grasindo, Jakarta

Lawson-Borders, G. (2003). Integrating new media and old media: Seven observations of convergence as a strategy for best practices in media organizations. International Journal on Media Management, 5(2), 91-99. https://doi.org/10.1080/14241270309390 023

Leksono, N., Advenita, M., Elmada, G., \& Kom, S. I. (2017). Menjangkau Pembaca Digital Sebuah Studi pada Kompas . id. 9(2), 1-15.

Lister, Martin. et all. (2009). New Media: A Critical Introduction. New York: Routledge.

McQuail, Dennis.(2011). Teori Komunikasi Massa McQuail. Jakarta: Salemba Humanika

Merrin, William. (2014). Media Studies 2.0. New York: Routledge

Neuman, W.L. (2014). Social Research Methods: Qualitative and Quantitative Approach. Pearson

Moleong. Lexy J. (2009) Metodologi Penelitian Kualitatif, Bandung: Remaja Rosdakarya

Oliver, J. (2013). 済無No Title No Title. In Journal of Chemical Information and Modeling (Vol. 53, Issue 9). https://doi.org/10.1017/CBO9781107415 324.004

Pavlik, J. V.(2001). Journalism and New Media. New York: Columbia University Press

R Diers, A. (2011). Reconceptualizing Mass Communication as Engagement: The Influence of Social Media. Journal of Mass Communication and Journalism, 
02(01), $1-2$.

https://doi.org/10.4172/2165-

$7912.1000 \mathrm{e} 104$

Sediyaningsih, S. (2018). Konvergensi Media

Di Era Digital (Eksploitasi Media

Komunikasi Dalam Proses Belajar Mengajar Di Era Digital). Jurnal Pendidikan Terbuka Dan Jarak Jauh, 19(1), 52-57. https://doi.org/10.33830/ptjj.v19i1.317.2 018

Straubhaar, Joseph. Robert Larose. Lucinda. (2011) Media Now: Understanding Media, Culture and Technology. USA : Wadsworth Group 
Bricolage : Jurnal Magister IImu Komunikasi Vol.6 (No. 1) : 100 - 136 Th. 2020 p-ISSN: 2502-0935 e-ISSN: 2615-6423 